\title{
Larval abundance patterns of Carcinus maenas (Decapoda, Brachyura) in Canal de Mira (Ria de Aveiro, Portugal)
}

\author{
Henrique Queiroga ${ }^{1}$, John D. Costlow ${ }^{2}$, Maria Helena Moreira ${ }^{1}$ \\ ${ }^{1}$ Departamento de Biologia, Universidade de Aveiro, P-3800 Aveiro, Portugal \\ ${ }^{2}$ Duke University Marine Laboratory, Pivers Island, Beaufort, North Carolina 28516-9721, USA
}

\begin{abstract}
Larval stages of Carcinus maenas (L.) were intensively sampled in the Canal de Mira (Ria de Aveiro, Portugall during 2 lunar months: February 12 to March 11 and May 9 to June 7, 1990. Each sampling period included fifteen $25 \mathrm{~h}$ fixed-station sampling cycles beginning at intervals of 4 tide cycles. Within each $25 \mathrm{~h}$ sampling cycle, plankton samples were collected hourly at several depths using a pump. Analysis of the data from these sampling periods indicated tidal and diel cycles of abundance of first stage $C$. maenas larvae. A semilunar component was also identified. These patterns were expressed as peaks of abundance during ebb tides, with highest peaks during nocturnal neap ebb tides around the first and last quarters of the moon. Peaks of nocturnal abundance could occur at any time during the night but consistently followed high water. In contrast, megalopae were present in the samples primarily during nocturnal flood tides. Intermediate zoeal stages of $C$. maenas were not collected. As indicated by an analysis of variance, the main effects of phases of the tide and day on the abundance of first zoeae and megalopae were significant $(p<0.05)$. These results provide evidence that a component with semilunar periodicity is associated with the release of $C$. maenas larvae. That the release activity occurs well after sunset is also an additional interesting feature of these observations, inasmuch as larval release in decapods is usually concentrated within the first few hours after dusk. These observations support earber observations that it is the time during the day-night cycle of high tide, as opposed to tidal amplitude, which is the important factor promoting synchrony with the lunar cycle.
\end{abstract}

KEY WORDS: Carcinus maenas - Larval stages - Estuaries - Abundance patterns - Hatching rhythms Recruitment · Portugal

\section{INTRODUCTION}

Rhythmicity of larval release is recognized as a phenomenon that strongly affects the transport and dispersion of larvae of coastal and estuarine decapods (Christy \& Stancyk 1982). Rhythmicity of larval release not only has a direct influence on larval mortality: it ultimately affects recruitment of the larvae to the parental populations. Although the literature on hatching rhythms of decapods has grown considerably during the last decade or so, the records concentrate, with few exceptions, on species from North and Central America and from Japan (see Christy 1982, De Coursey 1983 and Forward 1987 for reviews, but also De Vries \& Forward 1989). The mechanisms of recruitment of these larvae to the parental populations have also been intensively investigated on North and Central American species (Epifanio et al. 1984, Clancy \& Epifanio 1989, Dittel \& Epifanio 1990, Johnson \& Hess 1990, Dittel et al. 1991, Hill 1991, Little \& Epifanio 1991, to cite but a few of the more recent). Efforts made by European scientists to understand the mechanisms of larval transport in estuaries appear to be restricted to the earlier works on barnacles of the Wadden Sea by de Wolf $(1973,1974)$ and, more recently, to the study conducted by Paula (1989) on the rhythms of decapods' larval-releasing activity in a Portuguese estuary.

Carcinus maenas (L.) is one of the most common of the European coastal and estuarine crabs. It is also the most common crab in the Ria de Aveiro, Portugal, and is of local economic importance. The biology and ecology of juvenile and adult crabs are well studied (e.g. 
Broekhuysen 1936, Démeusy 1958, Naylor 1962, KleinBreteler 1975, 1976, Almaça 1982, Berrill 1982) but, except for the influence of food, salinity and temperature on larval development and some other scattered information (e.g. Lebour 1928, Rice 1966, Dawirs \& Dietrich 1986, Dawirs et al. 1986, Harms \& Seeger 1989, Mohamedeen \& Hartnoll 1989, Nagaraj 1993), no written account of the ecology of this species' larval phases exists.

This paper presents the first results of a study, currently under way, on the mechanisms of larval transport and recruitment of Carcinus maenas in the Canal de Mira, Ria de Aveiro. The following questions are addressed here: (1) What are the species' patterns of larval-release activity and how do these patterns relate to tidal, diel and lunar cycles? (2) What are the implications of the observed patterns to the transport of the larvae? (3) Are the larvae being exported out of the estuary? (4) If so, at what stage do they reinvade?

\section{METHODS}

This study took place in the Canal de Mira, one of the branches of the Ria de Aveiro (Fig. 1). The Canal de Mira is an elongated shallow arm that runs southward from the inlet for $20 \mathrm{~km}$. It receives continuous freshwater input at its head from a small system of ponds and rivers. It can be considered a small tidal estuary, for exchanges with the rest of the system are of small magnitude. Salinity conditions range from full salinity at the mouth to freshwater near the head. The Canal de Mira has a tidal period of $12 \mathrm{~h}$ and $20 \mathrm{~min}$. During the second and last quarters of the moon, neap high tides consistently occur early in the evening. Adult Carcinus maenas, including ovigerous females, live there, and post-larval recruitment is also known to occur there (Queiroga 1993).

Plankton sampling. In order to understand the patterns of abundance of Carcinus maenas larval stages, as related to tidal, diel and lunar cycles, plankton samples were collected during 2 sampling periods. Each period consisted of a series of fifteen 25 h fixed-station sampling cycles covering a complete lunar month. This was accomplished by alternately sampling 2 consecutive tidal cycles over a period of $25 \mathrm{~h}$ and leaving the next 2 tidal cycles unsampled. Plankton samples were collected with a centrifugal, gasoline-motor driven pump delivering approximately $0.5 \mathrm{~m}^{3} \mathrm{~min}^{-1}$. Pump output was measured and kept approximately constant for all samples. The water was passed through a specially designed $500 \mu \mathrm{m}$ net. The net was assembled on a frame that could be placed in the water and easily locked to a fiberglass boat gunwale, while keeping the net opening above water level. The pump output was directed to the surface of the water. This net design prevented the larvae from being flushed under pressure against the net and minimized larval damage and loss.

The first samplings were conducted in winter, from February 12 to March 11, 1990. Stn 2 (see Fig. 1) was used for all of the $25 \mathrm{~h}$ sampling cycles except one in which Stn 3 was used. Plankton samples were obtained every hour, in quick succession over $1 \mathrm{~m}$ depth intervals starting at $0.2 \mathrm{~m}$. When the last sample collected was located more than $0.5 \mathrm{~m}$ from the bottom, an extra sample was taken just above the bottom. The water volume filtered at each depth was on the order of $1 \mathrm{~m}^{3}$, corresponding to a pumping time of $2 \mathrm{~min}$.

The second sampling period, in spring, lasted from May 9 to June 7, 1990, and either Stn 1 or Stn 2 was used. Plankton samples were, again, obtained every hour, but only at 3 depths: $0.5 \mathrm{~m}$ below the surface, at mid depth, and $0.5 \mathrm{~m}$ above the bottom. During the second sampling period water was pumped for $5 \mathrm{~min}$ at each depth, providing filtered volumes of about $2.2 \mathrm{~m}^{3}$.

Sampling in both the first and the second periods was always started $4 \mathrm{~h}$ before the expected time of high water at the station. Meteorological or logistical circumstances prevented us from fully accomplishing the sampling program: $2 \frac{1}{2}$ sampling cycles in the
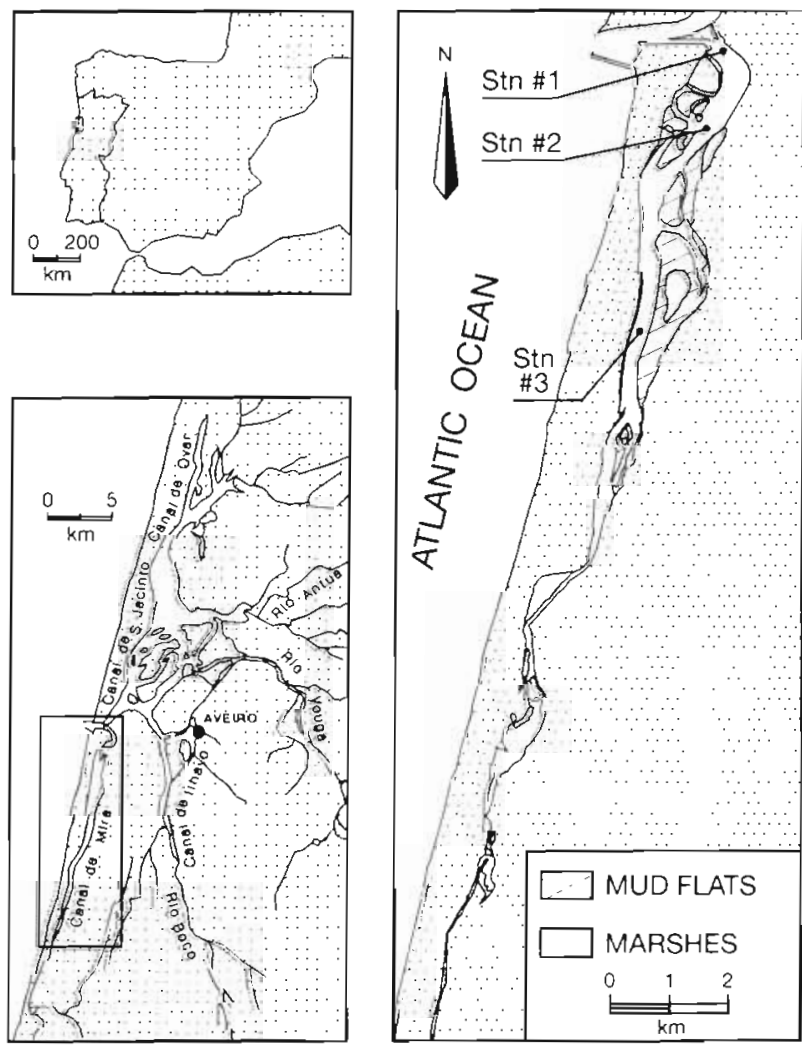

Fig. 1 The Ria de Aveiro and Canal de Mira, Portugal, showing location of sampling stations 
Fig. 2. Surface $(-)$ and bottom $(---)$ salinity and current velocity recorded during the $25 \mathrm{~h}$ sampling cycles of February 12 and 26, March 4, and May 11, 13 and 19, 1990, at Stn 2. Positive current velocity values refer to ebb velocities; negative values refer to flood velocities
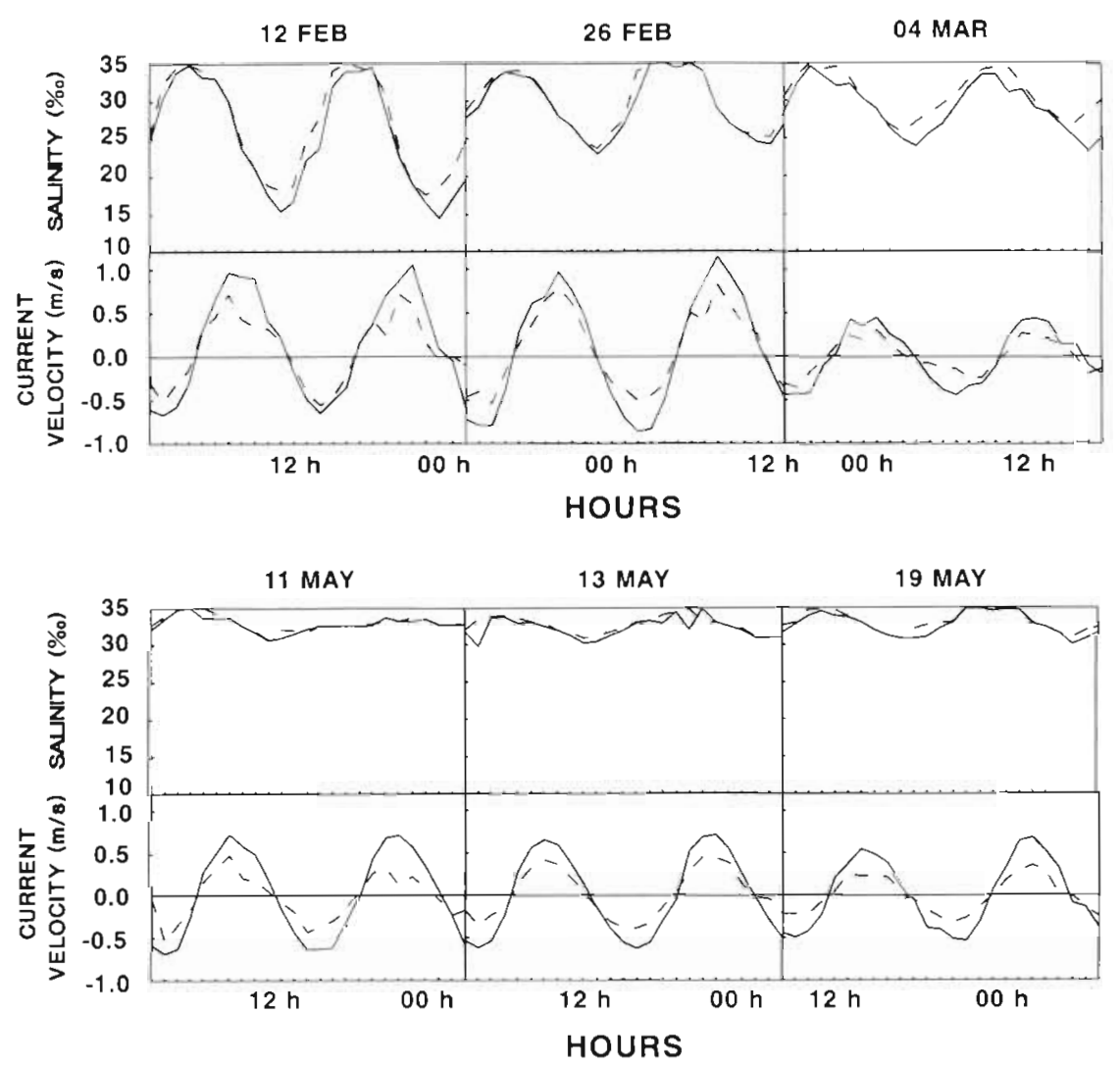

February/March period, and 2 in the May/June period, were cancelled.

Plankton samples were preserved in $4 \%$ buffered formaldehyde immediately after collection. Samples were not partitioned before counting. All Carcinus maenas larvae were identified to stage following Rice \& Ingle (1975). Abundance was expressed as number of larvae per $\mathrm{m}^{3}$.

Hydrological measurements. Hydrological parameters were read immediately before each hourly plankton sampling, always at $1 \mathrm{~m}$ depth intervals. Temperature and salinity were measured with a Yellow Springs Instrument Model $33 \mathrm{~S}-\mathrm{C}-\mathrm{T}$ meter. During some of the 25 h sampling cycles, data on velocity and direction of the current were also obtained with a Valeport, Braystroke type, BMF008 current meter. The hourly height of the tide was also measured with a sounding line.

\section{RESULTS}

\section{Hydrological characteristics of Stns $1 \& 2$}

The average water depths at Stns $1 \& 2$ are 6.5 and $4.3 \mathrm{~m}$ respectively. Average tidal amplitudes found during this study were about $2.3 \mathrm{~m}$ at Stn 1 and $2.1 \mathrm{~m}$ at Stn 2. Fig. 2 shows surface and bottom salinity and current velocity values for several of the tidal situations at Stn 2, for which a more extensive data set was obtained. Positive velocity values in Fig. 2 indicate ebb velocities, while negative values indicate flood. For simplicity, all the tides covered by each 25 h sampling cycle are referred to here by the starting date of that particular sampling cycle even if they would have actually occurred on the next calendar day. A notable feature of the data depicted in Fig. 2 is the narrower range of salinity fluctuation along the tidal cycle in spring (May 11, 13 and 19), compared with that found in late winter (February 12 and 26 and March 4). This range was about $17 \%$ and $11 \%$ on February 12 and 26 , 2 spring tide situations, and about $10 \%$ on March 4 , a neap tide situation. Salinity fluctuations registered on May 11, a spring tide situation, and May 13 and 19, neap tide situations, were less than $5 \%$. Fig. 3 gives, for comparison, the data obtained during the neap tides of May 21 at Stn 1. No major hydrological differences can be detected between these 2 stations, except perhaps the higher current velocities found at Stn 1.

Vertical water salinity stratification, if any, never exceeded $5 \%$ and occurred mostly during flooding.

\section{Patterns of larval abundance}

Only the first zoea and the megalopae of Carcinus maenas were found in the samples collected during the 


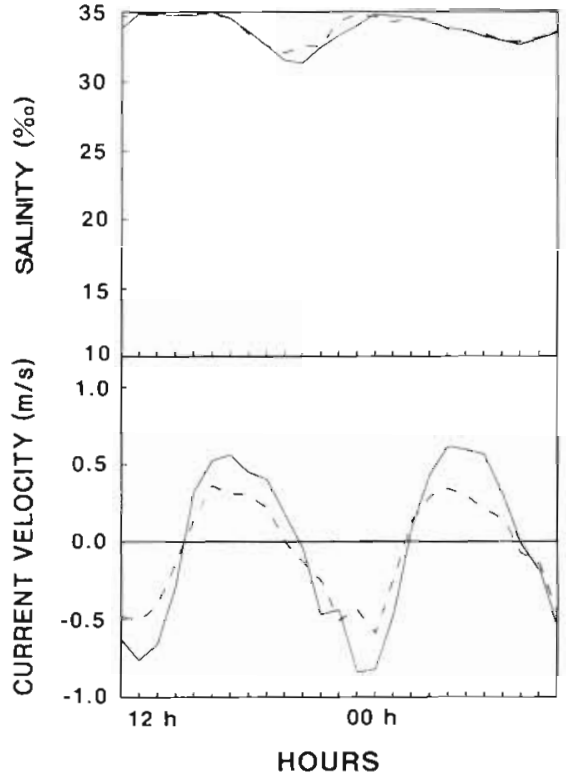

Fig. 3. Surface (-) and bottom (- - ) salinity and current velocity recorded during the $25 \mathrm{~h}$ sampling cycle of May 21, 1990, at Stn 1. Positive current velocity values refer to ebb velocities; negative values refer to flood velocities

2 sampling periods. First zoeae were $>4$ times more abundant in May/June than in February/March, while megalopae were only slightly more abundant in the

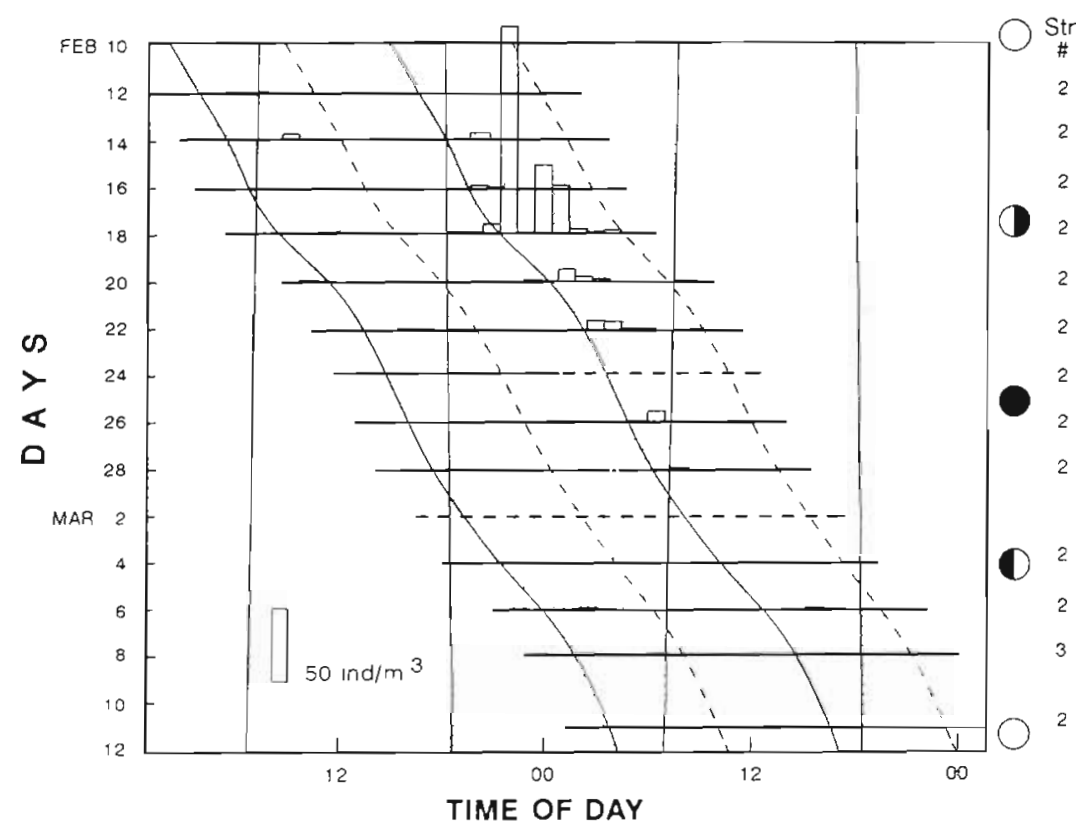

Fig. 4. Carcinus maenas. Hourly abundance of first zoeae during the sampling period of February/March 1990. Hourly values represent average abundance over the water column. Shaded areas: period between sunset and sunrise; solid line: high water; dashed line: low water; horizontal dashed lines: missing data. Time of day is local time spring than in the winter samples. Megalopal abundance was about 30 and 100 times lower than the abundance of first zoeae during winter and spring, respectively.

Figs, 4 \& 5 show the hourly abundance of first zoeae within each $25 \mathrm{~h}$ sampling cycle carried out in February/March and May/June, regardless of the sampling station where the data were obtained. Figs. 6 \& 7 show the same for the megalopae. In Figs. 4 to 7 larval abundance was averaged over depth. First zoeae were virtually absent during slack water but were found during flood and especially during ebb. Very high numbers of zoeae were observed during nighttime ebbing tides around the last quarter (see February 18 and May 15, 17, 19, 21 and 23 in Figs. 4 \& 5), and again, although not as intensely expressed, after the first quarter (see June 2 , 4 and 7 in Fig. 5). Unfortunately, because of pump malfunction, 2 sampling cycles are missing just before the first quarter. Still, the data in Figs. 4 \& 5 suggest a semilunar rhythm of larval release. Peaks of nocturnal abundance can occur at any time during the night, and sometimes even close to dawn, but consistently follow high water.

Figs. $6 \& 7$ are more difficult to analyze due to the scarcity of megalopae. Nevertheless, there are some indications that this larval stage is more abundant during flood tides and at night.

The tide-related pattern of occurrence of first zoeae and megalopae can best be observed in the pooled data plots for each larval stage, normalized around the time of high tide (Figs. $8 \& 9$ ). In these figures, all the abundance values obtained at the $1 \mathrm{~h}$ intervals before or after high tide were averaged for each sampling station and sampling period. As expected, first zoeae were more abundant during ebb tide (Fig. 8). At Stn 2, this stage attained maximum values 1 to $2 \mathrm{~h}$ before the more downstream Stn 1. Fig. 9 shows a clear concentration of megalopae during flood. Peak values for the megalopae occurred 3 to $4 \mathrm{~h}$ before high water at Stns 1 \& 2 , that is, within the first $3 \mathrm{~h}$ of the flood. The data from the only $25 \mathrm{~h}$ sampling cycle conducted at Stn 3 . during the sampling period of February/March, seem to indicate that the megalopae do not reach this station before the first $4 \mathrm{~h}$ of flood.

The data shown in Figs. 4 to 7 were separately subjected to analysis of 
variance (ANOVA), in order to test the significance of the effects of phase of tide and phase of day on the abundance of the first zoeae and the megalopae of Carcinus maenas, in each of the 2 sampling periods. Before the analysis, the data were rearranged as follows. The hourly larval catches were integrated over each $6 \mathrm{~h}$ tidal semi-period, producing a single value for the average abundance of larvae over each flood and each ebb tide. Since each sampling cycle was always started $4 \mathrm{~h}$ before expected high water, the 4 hourly samples of the first flood in each sampling cycle were combined with the first 2 hourly samples of the last flood. Thus, a period equivalent to 1 full flood tide was covered. Each flood and ebb tide was further classified as a nocturnal or diurnal tide, depending on whether more than half of its span would fall in the 'night' or in the 'day' phase. The day phase is the $12 \mathrm{~h}$ period centered between average sunrise and sunset times within each sampling period. The night phase is the complement of the day phase in the $24 \mathrm{~h}$ cycle. In addition, the data were square-root transformed and subdivided into blocks, each date constituting 1 block. Each block (date) was thus assigned the 4 possible combinations of levels of the factors phase of tide and phase of day: floodnight, flood-day, ebb-night and ebbday. This layout conforms to a 3-way ANOVA without replication (Sokal \& Rohlf 1969, p. 324-356), in which phase of tide and phase of day are fixed factors, each with 2 levels, and date is a random factor.

Table 1 summarizes the results of the ANOVAs. The phase-of-tide vs phase-of-day interaction was not found to be significant at the $5 \%$ level for first zoeae collected in winter, but was significant for the zoeae collected in spring. The main effects of tide and day were always significant at the $5 \%$ level, except for the effect of day in the winter-collected zoeae which was only significant at the $10 \%$ level. In the analysis of data for megalopae, the phase-of-tide vs phase-of-day

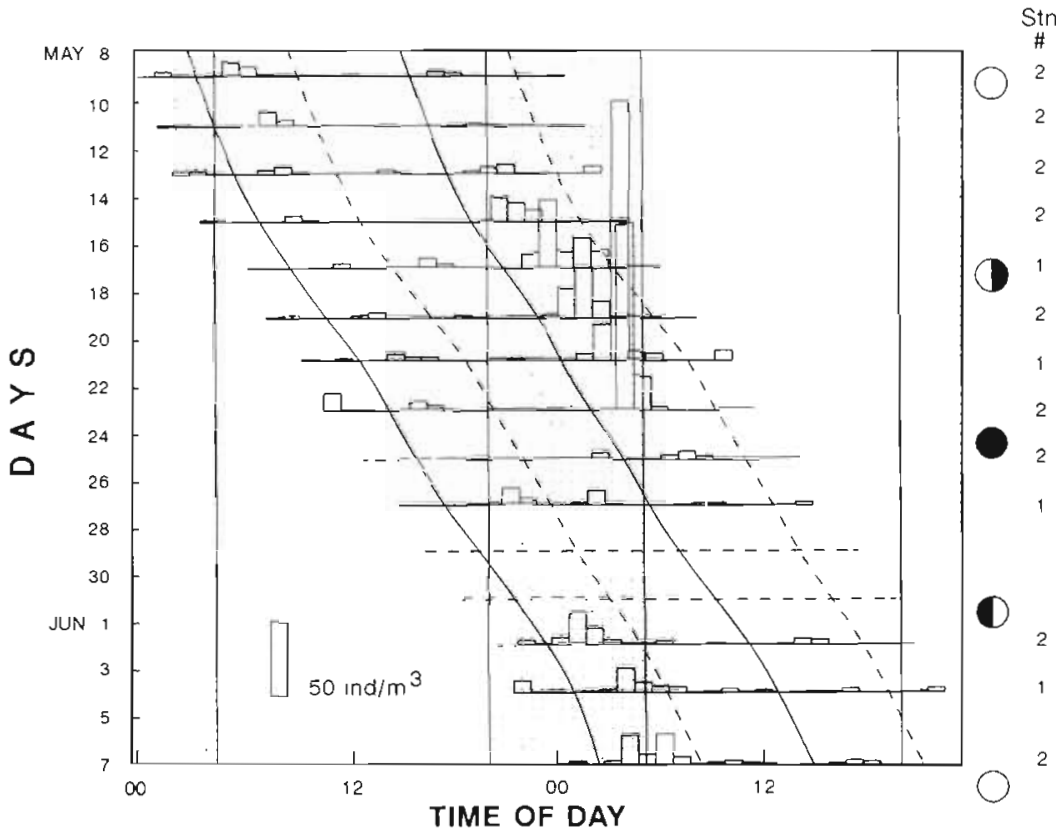

Fig. 5. Carcinus maenas. Hourly abundance of first zoeae during the sampling period of May/June 1990. Hourly values represent average abundance over the water column. Shaded areas: period between sunset and sunrise; solid line: high water; dashed line: low water; horizontal dashed lines: missing data. Time of day is local time

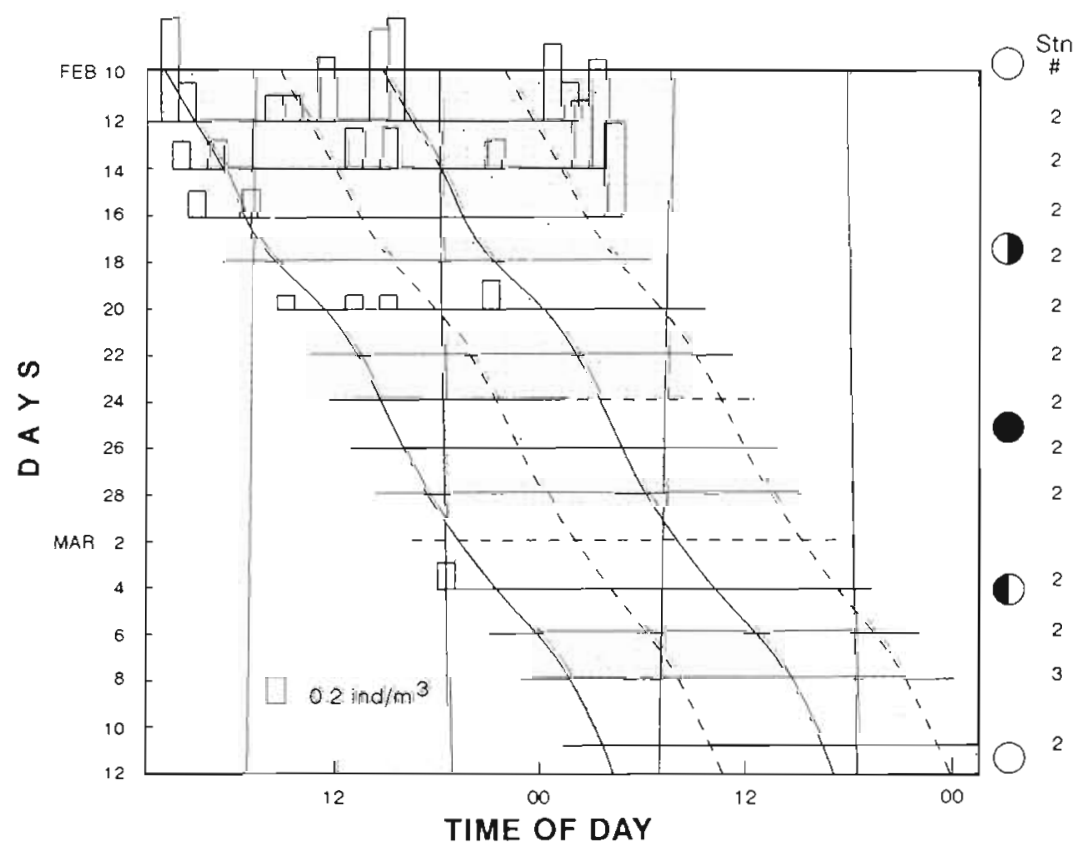

Fig. 6. Carcinus maenas. Hourly abundance of megalopae during the sampling period of February/March 1990. Hourly values represent average abundance over the water column. Shaded areas: period between sunset and sunrise; solid line: high water; dashed line: low water; horizontal dashed lines: missing data. Time of day is local time 


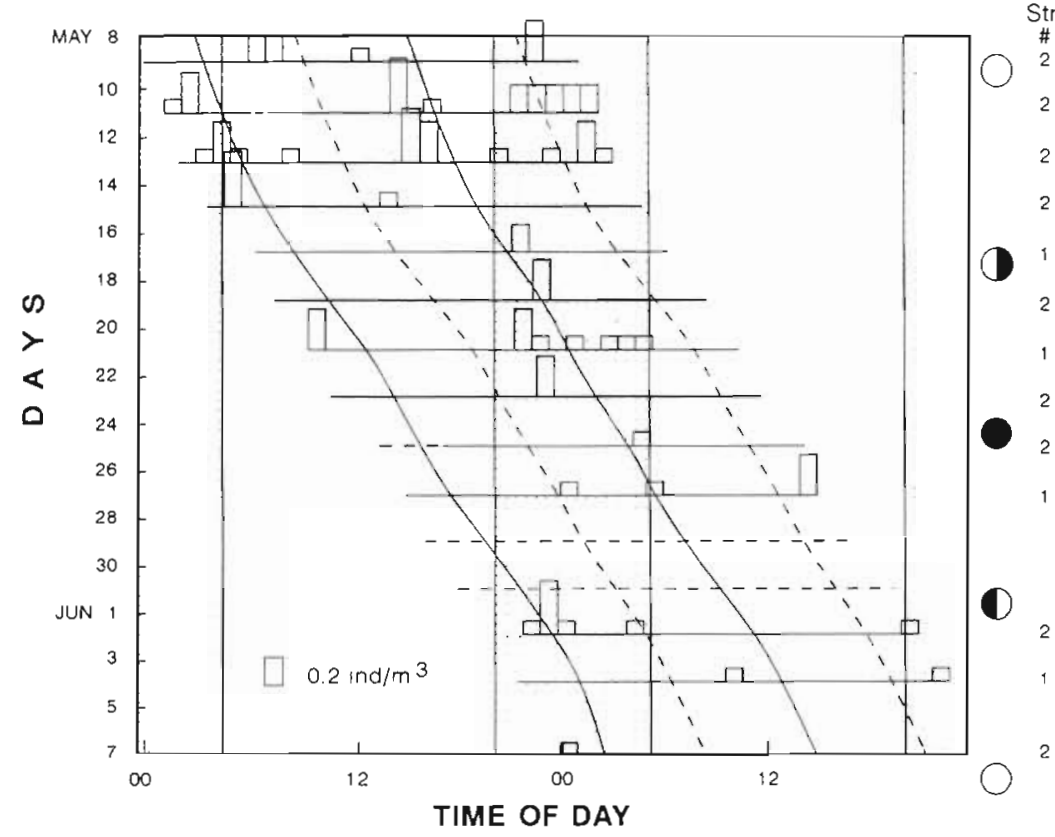

Fig. 7. Carcinus maenas. Hourly abundance of megalopae during the sampling period of May/June 1990. Hourly values represent average abundance over the water column. Shaded areas: period between sunset and sunrise; solid line: high water; dashed line: low water; horizontal dashed lines: missing data. Time of day is local time

interactions were found to be non-significant in both the winter-and spring-collected larvae. But, while the main effects of tide and day were highly significant in the spring-collected megalopae, the significance levels were less extreme in winter.

Figs. $10 \& 11$ show the effect of the phase-of-tide vs phase-of-day interaction for the zoeae and megalopae, respectively, collected during the February/March and May/June sampling periods. To evaluate the overall effects of phase of tide, phase of day and the phase-oftide vs phase-of-day interaction taking the 2 sampling periods simultaneously, a combined probabilities test (Sokal \& Rohlf 1969, p. 621) was applied to each of the effects. The results of these tests are shown in Tables 2 $\& 3$ for the first zoeae and megalopae respectively. For the first zoeae (Fig. 10, Table 2) the increase in concentration that takes place at night is more important during ebb than during flood. Taking both sampling periods simultaneously, this interaction is not significant at the $5 \%$ level. However, the main effects of phase of tide and phase of day are, on the whole, highly significant. For the megalopae (Fig. 11, Table 3), although the overall effect of night is more pronounced during flood than during ebb, this difference cannot be shown to be significant at the 5\% level. The main effects are, however, significant at the $5 \%$ level.

\section{DISCUSSION}

The chronology of reproductive events of Carcinus maenas in populations in the Wadden Sea, British Isles and English Channel is well known (Lebour 1928, Naylor 1962, Démeusy 1963, Klein-Breteler 1975, 1976). Although this species breeds throughout most of the year, ovigerous females are far more abundant during late winter and spring. Peaks of larval abundance in coastal waters coincide with spring and early summer and megalopae start to settle from May onwards. This pattern is shifted in time near the limits of the latitudinal range of the species. In Maine, USA (Berrill 1982), the breeding season is shorter and megalopae do not settle before July while on the Portuguese coast (Almaça 1982, Queiroga 1993) peaks of ovigerous female abundance (January/February) and of megalopae settlement (April to June) occur about 2 mo earlier than in the northern European populations. In the present study, more than 4 times more first-stage larvae were found in the May/June sampling experiments than in those of February/March. This is in accordance with the above-described pattern. Surprisingly, the overall abundance of the megalopae was about the same in the 2 sampling periods. One would expect higher densities of megalopae in late spring.

Table 1. Carcinus maenas. Summary of ANOVAs of the effects of phase of tide and phase of day on the abundance of first zoeae and megalopae

\begin{tabular}{|c|c|c|c|}
\hline & Phase of tide & Phase of day & $\begin{array}{c}\text { Phase of tide vs } \\
\text { Phase of day }\end{array}$ \\
\hline Zoea I, winter & $0.01>p>0.005$ & $0.10>p>0.05$ & $0.50>p>0.25$ \\
\hline Zoea I, spring & $p<0.001$ & $p<0.001$ & $0.05>p>0.025$ \\
\hline Megalopa, winter & $0.10>p>0.05$ & $0.25>p>0.10$ & $0.25>p>0.10$ \\
\hline Megalopa, spring & $p<0.001$ & $0.025>p>0.01$ & $0.25>p>0.10$ \\
\hline
\end{tabular}




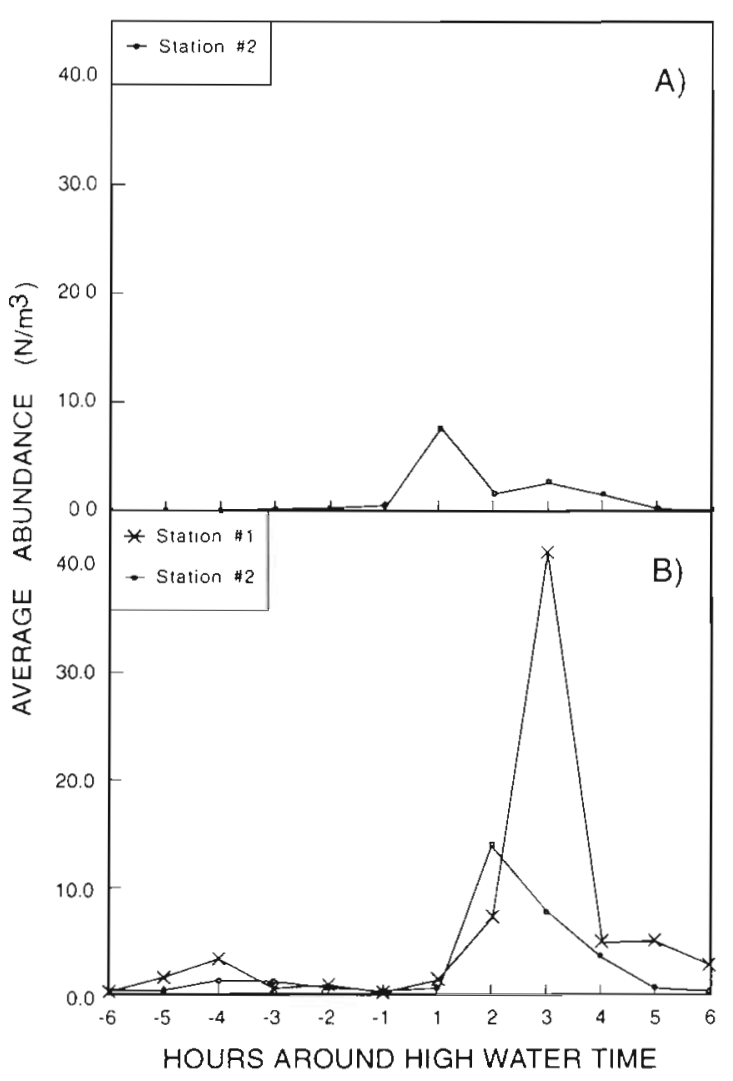

Fig. 8. Carcinus maenas. Average abundance of first zoeae at $1 \mathrm{~h}$ intervals before (negative hours) and after (positive hours) high water. All $25 \mathrm{~h}$ sampling cycles were pooled for Stns 1 and 2 within each sampling period: (A) February/March and (B) May/June

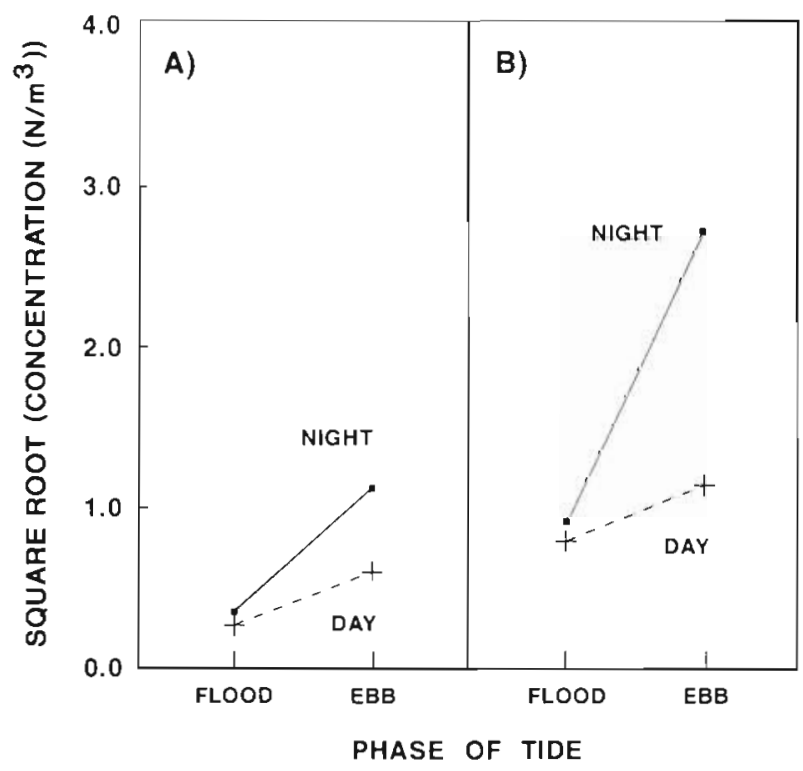

Fig. 10. Carcinus maenas. Effect of phase of tide and phase of day on abundance of first zoeae. All dates were combined within each sampling period: (A) February/March and (B) May/June

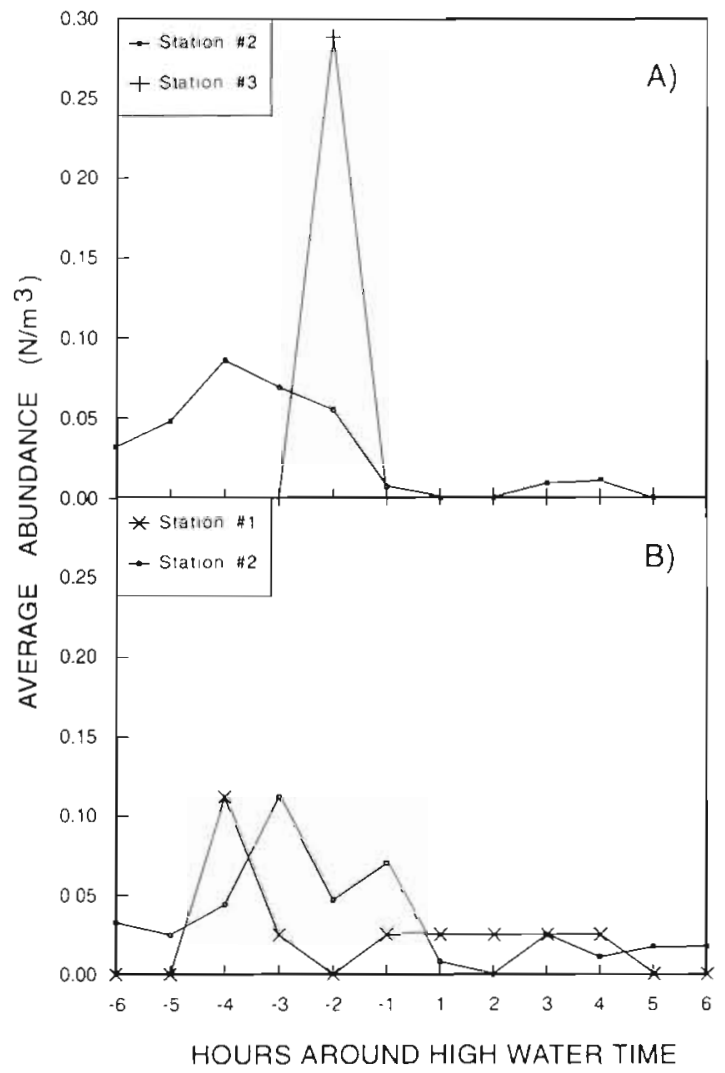

Fig. 9. Carcinus maenas. Average abundance of megalopae at $1 \mathrm{~h}$ intervals before (negative hours) and after (positive hours) high water. All 25 h sampling cycles were pooled for Stns 1, 2 and 3 within each sampling period: (A) February/March and (B) May/June

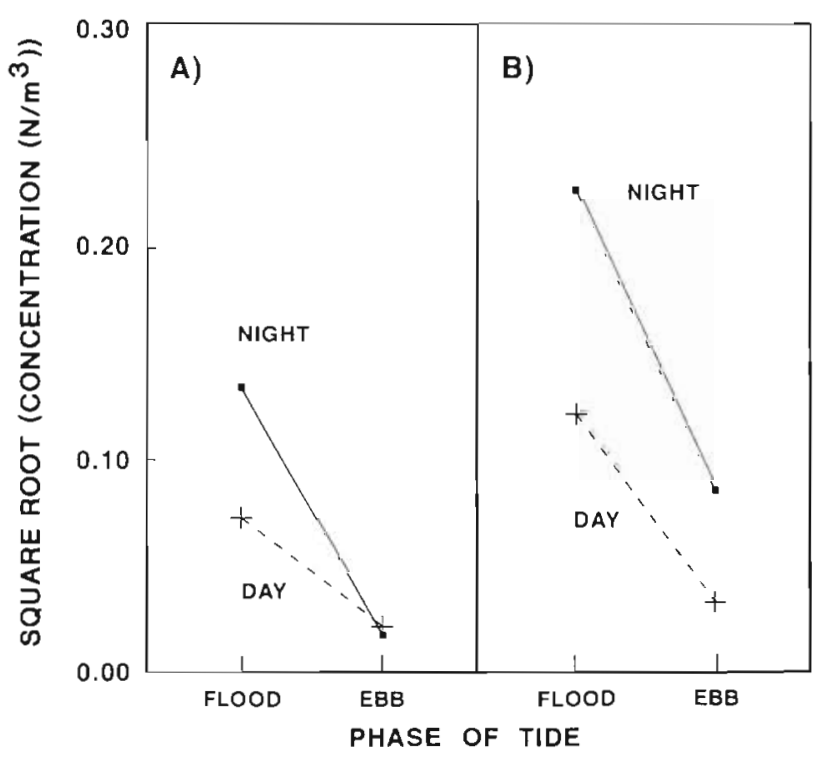

Fig. 11. Carcinus maenas. Effect of phase of tide and phase of day on abundance of megalopae All dates were combined within each sampling period: (A) February/March and (B) May/June 
Because the fate of the larvae that are exported to the sea is unknown, as are the mechanisms of transport over the shelf and the origin of the larvae that repopulate the Ria de Aveiro, it seems futile to speculate about the lack of seasonal difference in the megalopae, but this aspect of our results clearly deserves further study.

The present study shows tidal and diel cycles of abundance of first-stage Carcinus maenas larvae resulting from synchronous larval-releasing activity. During the February/March sampling period, larval release by $C$. maenas was only found during the last quarter of the moon. In May/June, releasing activity was also detected around the first quarter. These differences may be related to the fact that the breeding season had not reached its full peak in February/ March. Weak or aperiodic rhythms have been described in other estuarine decapod species when the observations were made early in their breeding seasons (Paula 1989). Nevertheless, the present results suggest that a component with a semilunar period is associated with the release of $C$. maenas larvae. They also indicate that the species releases the larvae primarily during nocturnal neap ebbing tides (first and third quarter moons). Yet, it should be noted that Paula (1989) did not find clear evidence of such a rhythm

Table 2. Carcinus maenas. Combined probabilities tests of the main effects of phase of tide and phase of day and of the phase of tide vs phase of day interaction, for first zoeae collected in the winter (February/March) and spring (May/June) sampling periods

\begin{tabular}{|c|c|}
\hline $\begin{array}{c}\text { Main effect of phase of } \mathrm{ti} \\
\text { Winter }\end{array}$ & Spring \\
\hline $\begin{aligned} F_{\mathrm{s}} & =11.917 \\
\mathrm{p} & =0.006\end{aligned}$ & $\begin{aligned} F_{\mathrm{s}} & =21.929 \\
\mathrm{p} & =0.0001\end{aligned}$ \\
\hline \multicolumn{2}{|c|}{$\begin{array}{l}\text { Combined probabilities test: } \\
\qquad \chi^{2}=28.653 \quad p<0.001 \quad \mathrm{df}=4\end{array}$} \\
\hline \multicolumn{2}{|l|}{ Main effect of phase of day } \\
\hline $\begin{aligned} F_{\mathrm{s}} & =3.435 \\
\mathrm{p} & =0.094\end{aligned}$ & $\begin{aligned} F_{s} & =19.673 \\
p & =0.00001\end{aligned}$ \\
\hline \multicolumn{2}{|c|}{$\begin{array}{l}\text { Combined probabilities test: } \\
\qquad \chi^{2}{ }_{s}=27.755 \quad p<0.001 \quad d f=4\end{array}$} \\
\hline \multicolumn{2}{|c|}{ Phase of tide vs phase of day interaction } \\
\hline $\begin{aligned} F_{\mathrm{s}} & =0.812 \\
\mathrm{p} & =0.417\end{aligned}$ & $\begin{aligned} F_{\mathrm{s}} & =6.256 \\
\mathrm{p} & =0.029\end{aligned}$ \\
\hline $\begin{aligned} \text { Combined probabilities } \\
$\[ \chi^{2}{ }_{s}=8.830 \quad 0.1 \]$\end{aligned}$ & $\begin{array}{l}\text { test: } \\
10>p>0.05 \quad d f=4\end{array}$ \\
\hline
\end{tabular}

associated with the release of $C$. maenas in the estuarine population of the southwestern Portuguese Mira River. Inspection of his data shows that the highest observed densities of first zoeae were about 6 ind. $\mathrm{m}^{-3}$, whereas in the present study peak densities approached 150 ind. $\mathrm{m}^{-3}$. It might be possible that Paula's data were obtained during a period when releasing activity of the species was at a minimum (i.e. after the main breeding season), thus not showing the 'normal' pattern.

Another notable feature of these data lies in the fact that during the periods corresponding to the nocturnal peaks of abundance of the first zoeae, this stage was present in the samples collected throughout the night i.e. the concentrations were not restricted to the first few hours after dusk as is usually the case for decapods (Forward 1987). It might be argued that the larvae caught at any particular station, in any particular sample taken during the span of the ebb, might not have hatched exclusively at that station but could have hatched upstream sometime before and been carried by the ebb current. That would place the moment of hatch some time earlier than is apparent in the graphs. We cannot deny that this may have influenced the data, but other aspects of the data indicate that this is not the full explanation. Inspection of Figs. $4 \& 5$ shows

Table 3. Carcinus maenas. Combined probabilities tests of the main effects of phase of tide and phase of day and of the phase of tide vs phase of day interaction, for megalopae collected in the winter (February/March) and spring (May/June) sampling periods

\begin{tabular}{|c|c|}
\hline $\begin{array}{c}\text { Main effect of phase of } \\
\text { Winter }\end{array}$ & Spring \\
\hline $\begin{aligned} F_{\mathrm{s}} & =4.402 \\
\mathrm{p} & =0.064\end{aligned}$ & $\begin{aligned} F_{\mathrm{s}} & =25.606 \\
\mathrm{p} & =0.0005\end{aligned}$ \\
\hline \multicolumn{2}{|c|}{$\begin{array}{l}\text { Combined probabilities test: } \\
\qquad \chi^{2}{ }_{s}=20.700 \quad p<0.001 \quad \text { df }=4\end{array}$} \\
\hline \multicolumn{2}{|c|}{ Main effect of phase of day } \\
\hline $\begin{aligned} F_{\mathrm{s}} & =1.765 \\
p & =0.225\end{aligned}$ & $\begin{aligned} F_{\mathrm{s}} & =6.823 \\
p & =0.024\end{aligned}$ \\
\hline \multicolumn{2}{|c|}{$\chi_{s}^{2}=10.443 \quad 0.05>p>0.025 \quad \mathrm{df}=4$} \\
\hline \multicolumn{2}{|c|}{ Phase of tide vs phase of day interaction } \\
\hline $\begin{aligned} F_{\mathrm{s}} & =3.140 \\
\mathrm{p} & =0.108\end{aligned}$ & $\begin{aligned} F_{\mathrm{s}} & =1.189 \\
\mathrm{p} & =0.211\end{aligned}$ \\
\hline $\begin{array}{l}\text { Combined probabilitie } \\
\qquad \chi_{s}^{2}=7.563\end{array}$ & test: \\
\hline
\end{tabular}


that at all 3 stations used in this study, first-stage larvae of Carcinus maenas began to appear in the water column about $1 \mathrm{~h}$ after high water (in Fig. 4, although they are not visible, a few larvae at $\operatorname{Stn} 3$ were collected around 01:00 $\mathrm{h}$ and again around 04:00 h). These larvae were certainly hatched near the station where the data were obtained, because of the weak current at the start of the ebb. During the sampling cycle of May 23 (Fig. 5), for instance, high water at Stn 2 occurred at 02:45 h, and the first larvae were collected at 04:00 h. This clearly places the release activity in the second part of the night.

The hatching activity of Carcinus maenas from the Canal de Mira seems to be controlled by a combination of solar day and time of high water. Female C. maenas begin releasing larvae in increasingly higher numbers as the high-water time approaches sunset. They continue to release in considerable numbers during the following days, as long as the time of high tide falls within $\mathrm{ca} 3 \mathrm{~h}$ before sunrise. C. maenas is usually found in the intertidal and shallow subtidal zones of rocky shores and estuaries (Broekhuysen 1936, Rasmussen 1959, Naylor 1962, Wolff \& Sandee 1971. Klein-Breteler 1976, Almaça 1982, Berrill 1982). Although juvenile crabs remain in the intertidal zone, in both of these habitats adults tend to perform tidal vertical migrations, retreating to the subtidal zone at low tide. They only remain between tide marks during summer, assuming that adequate shelter is available. However, ovigerous females, at least in estuaries, seem to be less active and seek deeper and more saline waters. Although no specific study on this topic has been pursued, ovigerous females of $C$. maenas were never found on the mud flats of the Canal de Mira during the many tens of hours of field work conducted by 2 of us in this habitat. However, they are common in the Canal de Mira below low water level (pers. obs.). Considering the physical stimuli that entrain the rhythmic release of larvae, and the adaptive value of such behavior, C. maenas must thus be considered a sublittoral species. Reports on rhythmical larvae-releasing behavior of estuarine sublittoral decapods include (1) the crab Callinectes arcuatus (De Vries et al. 1983) and the shrimps Palaemon spp. and Crangon crangon (Paula 1989), which show a semilunar rhythm; and (2) the crabs Rhithropanopeus harrisii (Forward et al. 1982), Callinectes sapidus, Neopanopeus spp., Pinnixia chaetopterana, Pinnotheres ostreum and Pinnotheres maculatum (Salmon et al. 1986), which do not show a semilunar rhythm. The results of the present study indicate that $C$. maenas constitutes another example of a sublittoral species that shows a semilunar rhythm in larval release. Thus, a semilunar rhythm may also be important for successful larval release of sublittoral decapod species (see Forward 1987).
Most previous studies on larval release rhythms of estuarine decapod crustaceans have had in common the finding that when a semilunar rhythm was present, release occurred around high water during crepuscular spring tides, independently of lunar phase (Forward 1987). Proposed functional advantages of this pattern are reduced exposure of larvae to detrimental combinations of low salinity and high temperatures, transport of larvae from shallow areas with high densities of planktivorous fish, a swamp effect on predators, and reduced probability of predation on females and larvae by visually hunting predators. Spring tides were thought necessary to maximize these effects. As pointed out by Paula (1989), these studies did not separate the effect of the onset of night from the effect of tidal amplitude. On the Portuguese coast, neap high tides occur early in the evening, and many of the species from the Mira estuary release their larvae during crepuscular neap high tides. This finding led Paula to propose that it is the time during the day-night cycle of high tide, rather than tidal amplitude (Christy 1982), which is the important factor promoting synchrony with the lunar month. Saigusa (1982) had already interpreted the timing mechanism of larval release in the terrestrial crab Sesarma haematocheir as a response to a combination of solar day and tide cycles. The described pattern of larval release by Carcinus maenas from the Canal de Mira, Ria de Aveiro, corroborates this theory.

The pattern of larval-releasing activity found for Carcinus maenas promotes a quick export of the first zoeae out of the estuary. Most of the larval development would then take place in the ocean, and the megalopae would be the stage that reinvades. Like several other reported cases (Callinectes sapidus and Callinectes sp.: Epifanio et al. 1984, Brookins \& Epifanio 1985, Epifanio 1988, Dittel \& Epifanio 1990, Little \& Epifanio 1991; UCa spp.: Brookins \& Epifanio 1985, Dittel \& Epifanio 1990, Little \& Epifanio 1991; Pinnotheres spp., Pinnixia spp., Petrolisthes spp.: Dittel \& Epifanio 1990) megalopae of this species are more abundant during flood and at night, suggesting that these tides provide the mechanism for travelling upstream in the estuary in search of suitable sites for settlement.

Acknowledgements. The authors thank Mr Fernando Morgado (Departamento de Biologia da Universidade de Aveiro) and the many students of the Departamento de Biologia who, through their interest and enthusiasm, made possible the successful accomplishment of field work. This study received financial support from Junta Nacional de Investigaçāo Científica e Tecnológica (Project no. 87/122), and was conducted while H.Q. was the holder of a scholarship granted by the Instituto Nacional de Investigação Científica. 


\section{LITERATURE CITED}

A.maça, C. (1982). Note sur la biologie des populations de Carcinus maenas (L.) de la zone intertidale du Portugal occidental. Quad. Lab. Tecnol. Pesca, Ancona 3(2-5) $179-185$

Berrill, M. (1982). The life cycle of the green crab Carcinus maenas at the northern end of its range. J. Crust. Biol. 2(1): $31-39$

Broekhuysen, G. J. Jr (1936). On development, growth and distribution of Carcinides maenas (L.). Archs Néerl. Zool. 2: $257-399$

Brookins, K. G., Epifanio, C. E. (1985). Abundance of brachyuran larvae in a small coastal inlet over six consecutive tidal cycles. Estuaries 8(1): 60-67

Christy, J. H. (1982). Adaptive significance of semilunar cycles of larval release in fiddler crabs (genus $U c a$ ); test of an hypothesis. Biol. Bull. 163; 251-263

Christy, J. H., Stancyk, S. E. (1982). Timing of larval production and flux of invertebrate larvae in a well-mixed estuary. In: Kennedy, V. S. (ed.) Estuarine comparisons. Academic Press, New York, p. 489-503

Clancy, M., Epifanio, C. E. (1989). Distribution of crab larvae in relation to tidal fronts in Delaware Bay, USA. Mar. Ecol Prog. Ser. 57: 77-82

Dawirs, R. R., Dietrich, A. (1986). Temperature and laboratory feeding rates in Carcinus maenas L. (Decapoda: Portunidae) larvae from hatching through metamorphosis. J. exp. mar. Biol. Ecol. 99: 133-147

Dawirs, R. R., Puschel, C., Schorn, F. (1986). Temperature and growth in Carcinus maenas L. (Decapoda: Portunidae) larvae reared in the laboratory from hatching through metamorphosis. J. exp. mar. Biol. Ecol. 100: 47-74

De Coursey, P. J. (1983). Biological timing. In: Bliss, D., Vernberg. F., Vernberg, W. (eds.) The biology of Crustacea, Vol. 7, Behavior and ecology. Academic Press, New York, p. $107-162$

Démeusy, N. (1958). Recherches sur la mue de puberté du décapode brachyure Carcinus maenas Linné. Archs Zool. exp. gén. 95(8): 253-491

Démeusy, N. (1963). Étude d'une population de Carcinus maenas L. des côtes de la Manche: cycle génital et ovarien. C.r. Acad. Sci., Paris 256(5): 4095-4097

De Vries, M. C., Epifanio, C. E., Dittel, A. I. (1983). Lunar rhythms in egg hatching of the subtidal crustacean: Callinectes arcuatus Ordway (Decapoda: Brachyura). Estuar. coast. Shelf Sci. 17: 717-724

De Vries, M. C., Forward, R. B. Jr (1989). Rhythms in larval release of the sublittoral crab Neopanope sayi and the supralittoral crab Sesarma cinereum (Decapoda: Brachyura). Mar. Biol. 100: 241-248

de Wolf, P. (1973). Ecological observations on the mechanisms of dispersal of barnacle larvae during planktonic life and settling. Neth. J. Sea Res. 6(1-2): 1-129

de Wolf, P. (1974). On the retension of marine larvae in estuaries. Thalassia jugosl. 10(1/2): 415-424

Dittel, A. I., Epifanio, C. E. (1990). Seasonal and tidal abundance of crab larvae in a tropical mangrove system, Gulf of Nicoya, Costa Rica. Mar. Ecol. Prog. Ser. 65: 25-34

Dittel, A. I., Epifanio, C. E., Lizano, O. (1991). Flux of crab larvae in a mangrove creek in the Gulf of Nicoya, Costa Rica. Estuar. coast. Shelf Sci. 32: 129-140

Epifanio, C. E. (1988). Transport of invertebrate larvae between estuaries and the continental shelf. Am. Fish. Soc. Symp. 3: 104-114

Epifanio, C. E., Valenti, C. C., Pembroke, A. E. (1984). Disper-

This article was submitted to the editor sal and recruitment of blue crab larvae in Delaware Bay, USA. Estuar. coast. Shelf Sci. 18:1-12

Forward, R. B. Jr (1987). Larval release rhythms of decapod crustaceans: an overview. Bull. mar. Sci. 41(2): 165-176

Forward, R. B. Jr, Lohmann, K., Cronin, T W. (1982). Rhythms in larval release by an estuarine crab (Rhithropanopeus harrisii). Biol. Bull. 163: 287-300

Harms, J., Seeger, B. (1989). Larval development and survival in seven decapod species (Crustacea) in relation to laboratory diet. J. exp. mar. Biol. Ecol, 133: 129-139

Hill, A. E. (1991). Advection-difusion-mortality solutions for investigating pelagic larval dispersal. Mar. Ecol. Prog. Ser. 70: $117-128$

Johnson, D. F., Hess, K. W. (1990). Numerical simulations of blue crab larval dispersal and recruitment. Bull. mar. Sci. 46(1): 195-213

Klein-Breteler, W. C. M. (1975). Growth and moulting of juvenile shore crabs, Carcinus maenas, in a natural population. Neth. J. Sea Res. 9(1): 86-99

Klein-Breteler, W. C. M. (1976). Settlement, growth and production of the shore crabs, Carcinus maenas, on tidal flats in the Dutch Wadden Sea. Neth. J. Sea Res. 10(3): 354-376

Lebour, M.-V. (1928). The larval stages of Plymouth Brachyura. Proc. Zool. Soc. Lond. 34: 473-560

Little, K. T., Epifanio, C. E. (1991). Mechanisms for the reinvasion of an estuary by two species of brachyuran megalopae. Mar. Ecol. Prog. Ser. 68: 235-242

Mohamedeen, H., Hartnoll, R. G. (1989). Larval and postlarval growth of individually reared specimens of the common shore crab Carcinus maenas L. J. exp. mar. Biol. Ecol. 134: $1-24$

Nagaraj, M. (1993). Combined effects of temperature and salinity on the zoeal development of the green crab, Carcinus maenas (Linnaeus, 1758) (Decapoda: Portunidae). Scient. mar. 57(1): $1-8$

Naylor, E. (1962). Seasonal changes in a population of Carcinus maenas (L.) in the littoral zone. J. Anim. Ecol. 31(3): $601-609$

Paula, J. (1989). Rhythms of larval release of decapod crustaceans in the Mira Estuary, Portugal. Mar. Biol. 100: 309-312

Queiroga, H. (1993). An analysis of the size structure of Carcinus maenas (L.) (Decapoda, Brachyura) from Canal de Mira, Ria de Aveiro, Portugal. Bios 1(1): 89-106

Rasmussen, E. (1959). Behaviour of sacculinized shore crabs (Carcinus maenas Pennant). Nature 183: 479-480

Rice, A. L. (1966). The orientation of the pressure response of some marine Crustacea. Proc. Symp. on Crustacea. Mar. Biol. Ass. India, Part III, p. 1124-1131

Rice, A. L., Ingle, R. W. (1975). The larval development of Carcinus maenas (L.) and C. mediterraneus Czerniavsky (Crustacea, Brachyura, Portunidae) reared in the laboratory. Bull. Br. Mus. nat. Hist. (Zool.) 28: 103-119

Saigusa, M. (1982). Larval release rhythm coinciding with solar day and tide cycles in the terrestrial crab Sesarma -harmony with the semilunar timing and its adaptive significance. Biol. Bull. 162: 371-386

Salmon, M., Seiple, W H., Morgan, S. G. (1986). Hatching rhythms of fiddler crabs and associated species at Beaufort, North Carolina. J. Crust. Biol. 6(1): 24-36

Sokal, R. R., Rohlf, F. J. (1969). Biometry. W. H. Freeman and Co., San Francisco

Wolff, W. J., Sandee, A. J. J. (19?1). Distribution and ecology of the Decapoda Reptantia of the estuarine area of the Rivers Rhine, Meuse and Scheldt. Neth. J. Sea Res. 5(2): $197-226$

Manuscript first received: September 21, 1993

Revised version accepted: April 13, 1994 